\title{
Exuvium adatok Somogy megye szitakötő faunájához (Insecta: Odonata)
}

\author{
BORSOS SÁNDOR
}

H-7570 Barcs, Dohány utca 9., Hungary email: sborsos@index.hu

\begin{abstract}
Borsos, S.: Data regarding the exuviae of the dragonfly fauna of Somogy county (Insecta: Odonata). Abstract: In this paper, the data of 393 exuviae can be found, all of which were collected during the time period of nine years, namely from 29th of April, 2011 to the 11th of September, 2020. Altogether, 2168 specimens were collected, from 27 different habitats, mostly from territories closely related to the river Dráva.
\end{abstract}

Keywords: faunistic, Drava river, Hungary

\section{Bevezetés}

Somogy megye szitakötő faunájára nézve a legelső ismert adatokat Kohaut Rezső „,A magyarországi szitakötö-félék természetrajza” c. munkájában találjuk a XIX. század végéről (KoHAUT 1896). A terület rovartani kutatása a XX. század második felében gyorsult fel igazán. A szitakötő fauna alaposabb megismerésében jelentős munkát végeztek Dévai György és munkatársai, akik többek között a Barcs és Darány közötti területeken (DÉVAI 1981, DÉvaI és Miskolczi 2010a, DÉvAI et al. 1978, 1993), a Zselicben és a Dráva mentén (DÉVAI és MisKolczi 2010c, b) folytattak gyüjtéseket. Ki kell emelnünk Tóth Sándor nevét, aki a Boronka-melléki Tájvédelmi Körzettöl a Zselicen át a Dráva mente területéig az egész megyében fontos feltáró munkát végzett (Тóтн 1995, 1998, 2003, 2005, 2006, 2010). Somogy megye szitakötőinek katalógusa is az ő nevéhez füződik (TóTH 2001). Elsősorban a Drávához kapcsolódó szórványos lárva és exuvium adatok szerepelnek Kovács et al. (2004) közleményében. Az utóbbi évekből említhető Móra Arnoldnak a barcsi Ó-Dráván folytatott kutatómunkája (MóRA 2019).

\section{Anyag és módszer}

Az exuviumok gyüjtése egyeléssel történt. A fajok azonosításához FARKAS (2020, 2021) valamint KovÁcs et al. (2018) munkáit használtam. A begyüjtött lárvabőrök tárolása száraz állapotban, dobozokban történt. Az üledékkel fedett, nehezen tisztítható lárvabörök bizonytalan adatainak közlésétől eltekintettem. A Chalcolestes parvidens (Artobolevskij, 1929) és a Chalcolestes viridis (Van der Linden, 1825) fajok exuviumainak elkülönítése a mai napig nehézkes, ezért ezek adatait Chalcholestes parvidens/ viridis megjelöléssel közöltem. 
1. táblázat: A lelőhelyek koordinátái

\begin{tabular}{|c|c|c|}
\hline \multirow{2}{*}{ Lelőhely } & \multicolumn{2}{|c|}{ Koordináták } \\
\hline & Szélesség & Hosszúság \\
\hline Balatonfenyves, Tenkes utca & N46연 $34^{\prime \prime}$ & $\mathrm{E} 17^{\circ} 26^{\prime} 48^{\prime \prime}$ \\
\hline Balatonmáriafürdő, Nyugati-övcsatorna & 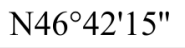 & $\mathrm{E} 17^{\circ} 22^{\prime} 51^{\prime \prime}$ \\
\hline Barcs, 9. tó & $\mathrm{N} 45^{\circ} 58^{\prime} 30^{\prime \prime}$ & $\mathrm{E} 17^{\circ} 32^{\prime} 15^{\prime \prime}$ \\
\hline Barcs, Dráva, kikötő & N455'ㅇ' & $\mathrm{E} 17^{\circ} 26^{\prime} 44^{\prime \prime}$ \\
\hline Barcs, Dráva, Ringló & $\mathrm{N} 45^{\circ} 57^{\prime} 06^{\prime \prime}$ & $\mathrm{E} 17^{\circ} 23^{\prime} 15^{\prime \prime}$ \\
\hline Barcs, Dráva, strand & $\mathrm{N} 45^{\circ} 56^{\prime} 46^{\prime \prime}$ & $\mathrm{E} 17^{\circ} 27^{\prime} 48^{\prime \prime}$ \\
\hline Barcs, Dráva-part & N4556'39" & $\mathrm{E} 17^{\circ} 28^{\prime} 10^{\prime \prime}$ \\
\hline Barcs, Kis-Bók & $\mathrm{N} 45^{\circ} 57^{\prime} 05^{\prime \prime}$ & E1730'46" \\
\hline Barcs, Ó-Dráva & N45 $57^{\prime} 36^{\prime \prime}$ & $\mathrm{E} 17^{\circ} 23^{\prime} 31^{\prime \prime}$ \\
\hline Barcs, Rinya, BSC & N455'ㅇ' & $\mathrm{E} 17^{\circ} 26^{\prime} 42^{\prime \prime}$ \\
\hline Barcs, Rinya, vasútállomás & $\mathrm{N} 45^{\circ} 57^{\prime} 10^{\prime \prime}$ & $\mathrm{E} 17^{\circ} 266^{\prime} 51^{\prime \prime}$ \\
\hline Barcs, Vöröspart & N455'ㅇ' & $\mathrm{E} 17^{\circ} 30^{\prime} 20^{\prime \prime}$ \\
\hline Barcs, Zimona & $\mathrm{N} 45^{\circ} 56^{\prime} 38^{\prime \prime}$ & $\mathrm{E} 17^{\circ} 28^{\prime} 28^{\prime \prime}$ \\
\hline Bélavár, bányatavak & 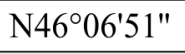 & $\mathrm{E} 17^{\circ} 12^{\prime} 26^{\prime \prime}$ \\
\hline Darány, Kaburgya & N4559'50" & E17º33'51" \\
\hline Darány, Kerek-tó & N460'09" & E173'06" \\
\hline Darány, Nagyberek & N4559'37" & E17³3'34" \\
\hline Darány, Nyírkút & $\mathrm{N} 45^{\circ} 57^{\prime} 53^{\prime \prime}$ & $\mathrm{E} 17^{\circ} 33^{\prime} 48^{\prime \prime}$ \\
\hline Kaposvár, Deseda-víztározó & $\mathrm{N} 46^{\circ} 26^{\prime} 30^{\prime \prime}$ & $\mathrm{E} 17^{\circ} 47^{\prime} 45^{\prime \prime}$ \\
\hline Kaposvár, Hódos-tó-ér & N46ํำ' $19^{\prime} 50^{\prime \prime}$ & $\mathrm{E} 17^{\circ} 47^{\prime} 49^{\prime \prime}$ \\
\hline Kaposvár, Hódos-tó & N4619'15" & $\mathrm{E} 17^{\circ} 47^{\prime} 49^{\prime \prime}$ \\
\hline Kaposvár, Töröcskei-tó & N46ํำ' $19^{\prime \prime \prime}$ & $\mathrm{E} 17^{\circ} 46^{\prime} 29^{\prime \prime}$ \\
\hline Marcali, Boronka-patak & $\mathrm{N} 46^{\circ} 35^{\prime} 06^{\prime \prime}$ & $\mathrm{E} 17^{\circ} 26^{\prime} 43^{\prime \prime}$ \\
\hline Marcali, Gyótapusztai halastó & N4632'32" & $\mathrm{E} 17^{\circ} 27^{\prime} 15^{\prime \prime}$ \\
\hline Somogytarnóca, horgásztó & $\mathrm{N} 46^{\circ} 00^{\prime} 20^{\prime \prime}$ & $\mathrm{E} 17^{\circ} 28^{\prime} 01^{\prime \prime}$ \\
\hline Szenna, Mátyás-kút & $\mathrm{N} 46^{\circ} 15^{\prime} 00^{\prime \prime}$ & E1741'53" \\
\hline Vörs, Zala-torkolat & 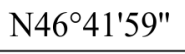 & $\mathrm{E} 17^{\circ} 15^{\prime} 27^{\prime \prime}$ \\
\hline
\end{tabular}

A fajok felsorolásánál Kovícs et al. (2018) könyvében szereplő rendszert és nevezéktant követtem.

A közleményben szereplő lárvabőrök a Rippl-Rónai Múzeum (Kaposvár) gyüjteményében kerültek elhelyezésre, kivéve a *-al jelzett tételek, ezek a szerző magángyüjteményében találhatók. 


\section{Eredmények}

Az alábbi közleményben a 2011.04.29-től 2020.07.11-ig terjedő időszakban Somogymegyében gyüjtött szitakötő exuviumok 393 adata szerepel. A lárvabörök 27 lelőhelyről kerültek elő, döntő többségükben Dráva menti területekről (1. táblázat).

\section{ZYGOPTERA Selys, 1854 \\ Lestidae Calvert, 1901}

Chalcolestes parvidens (Artobolevskij, 1929)/viridis (Vander Linden, 1825): Balatonfenyves, Tenkes utca: 2014.06.21., 2 - Darány, Nyírkút: 2018.06.19., 1 - Darány, Nagyberek: 2014.07.02., 1 - Marcali, Gyótapusztai halastó: 2018.05.20., 1.

\section{Calopterygidae Selys, 1850}

Calopteryx splendens (Harris, 1780): Barcs, Dráva, kikötő: 2014.06.05., 1; 2014.06.19., 2; 2015.05.04., 1; 2015.07.10., 1; 2016.04.22., 1; 2016.05.23., 1 - Barcs, Dráva, Ringló: 2020.05.09. 1 - Barcs, Rinya, BSC: 2011.05.20., 2; 2016.05.07., 1; 2016.05.20., 1; 2016.06.07., 1; 2018.05.07., 2 - Barcs, Rinya, vasútállomás: 2015.06.16., 2.

\section{Platycnemididae Tillyard, 1917}

Platycnemis pennipes (Pallas, 1771): Balatonmáriafürdő, Nyugati-övcsatorna: 2018.07.02., 1 - Barcs, Dráva, kikötő: 2014.06.19., 2 - Barcs, Kisbók: 2015.05.09., 1; 2018.05.29., 1;2019.05.10., 2 - Barcs, Rinya, vasútállomás: 2015.06.16., 20; 2015.06.25., 5 - Barcs, Vöröspart: 2014.06.05., 1; 2015.06.13., 4; 2015.06.25., 1; 2016.06.08., 1; 2016.06.14., 3; 2017.05.21., 1; 2018.05.08., 1; 2018.05.16., 1; 2018.06.07., 1; 2019.04.28., 1; 2020.05.03., 1; 2020.05.10., 10; 2020.06.02., 7; 2020.06.06., 4; 2020.06.25., 1 - Barcs, Zimona: 2011.07.03., 2; 2015.05.12., 2 - Bélavár, bányatavak: 2020.05.09., 7 - Kaposvár, Hódos-tó: 2018.06.26., 1 - Kaposvár, Töröcskei-tó:

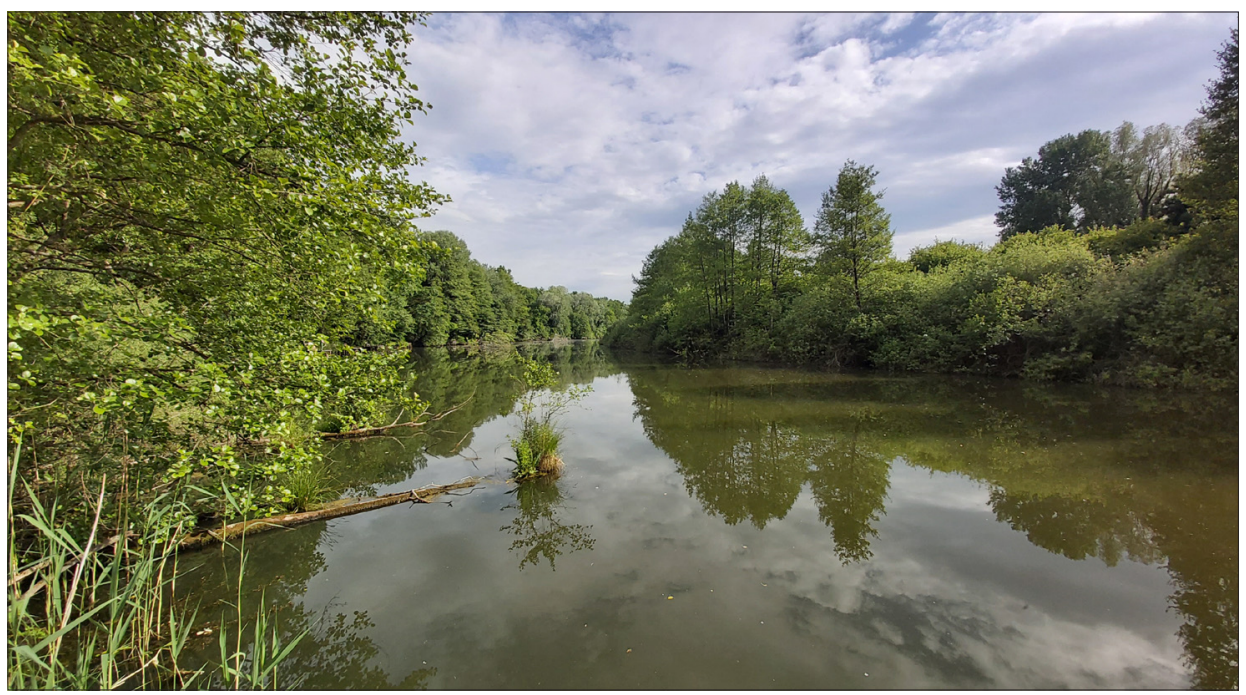

1. ábra: A Vöröspart Barcsnál 
2020.05.13., 9 - Marcali, Gyótapusztai halastó: 2014.06.09., 1 - Somogytarnóca, horgásztó: 2018.05.12., 19.

Coenagrionidae Kennedy, 1920

Coenagrion puella (Linnaeus, 1758): Barcs, 9. tó: 2014.05.10., 4; 2015.05.04., 3 Barcs, Kisbók: 2015.05.09., 10 - Barcs, Ó-Dráva: 2018.05.17., 7; 2020.04.22., 4; 2020.05.02., 3; 2020.05.07., 2 - Barcs, Rinya, BSC: 2011.05.20., 1; 2018.05.07., 4 Barcs, Rinya, vasútállomás: 2015.06.25., 1 - Barcs, Vöröspart: 2015.05.11., 6; 2016.05.21., 6; 2017.05.21., 6; 2019.04.28., 1 - Darány, Kaburgya: 2015.05.06., 2 Darány, Nagyberek: 2014.05.21., 12; 2016.05.21., 5 - Kaposvár, Töröcskei-tó: 2020.05.13., 1 .

Coenagrion pulchellum (Vander Linden, 1825): Barcs, 9. tó: 2014.05.24., 1; 2015.05.04., 3; 2015.05.07., 1; 2016.05.08., 4 - Barcs, Kisbók: 2015.05.09., 4 - Barcs, Ó-Dráva: 2018.05.17., 3; 2020.04.22., 6; 2020.05.02., 3 - Barcs, Rinya, BSC: 2011.05.20., 1; 2018.05.07., 2; 2020.05.02., 1 - Barcs, Rinya, vasútállomás: 2015.06.16., 1 - Barcs, Vöröspart: 2015.05.11., 4; 2016.05.09., 3; 2016.05.21., 8; 2016.05.25., 1; 2016.06.14., 2; 2017.05.30., 3 - Darány, Nagyberek: 2016.05.21., 3; 2014.15.21., 5. $1 *$.

Erythromma viridulum (Charpentier, 1840): Marcali, Gyótapusztai halastó: 2014.06.09.,

Ischnura elegans (Vander Linden, 1820): Balatonmáriafürdő, Nyugati-övcsatorna: 2015.05.17., 1 - Barcs, 9. tó: 2014.05.10., 2 - Barcs, Vöröspart: 2016.05.25., 1.

\section{ANISOPTERA Selys, 1854 \\ Aeshnidae Rumbur, 1842}

Aeshna affinis (Vander Linden, 1820) - Balatonfenyves, Tenkes utca: 2014.06.21., 1 Barcs, 9. tó: 2013.06.19., 3 - Darány, Nyírkút: 2018.06.19., 1 - Darány, Nagyberek: 2014.07.02., 4.

Aeshna isoceles (Müller, 1767) - Barcs, 9. tó: 2016.05.08., 1 - Barcs, Ó-Dráva: 2018.05.17., 5; 2020.05.07., 1 - Barcs, Rinya, BSC: 2011.05.20., 1; 2018.05.07., 12 Barcs, Vöröspart: 2014.06.05., 4; 2015.05.09., 3; 2015.05.11., 1*; 2015.06.13., 2; 2015.06.23., 1; 2016.05.25., 4; 2016.06.08., 3; 2016.06.14., 2; 2017.05.21., 2; 2017.05.30., 5; 2018.05.08., 4; 2018.05.16., 6; 2018.05.21., 9; 2019.05.08., 1; 2020.05.03., 1; 2020.05.04., 1; 2020.06.03., 2 - Darány, Nagyberek: 2014.05.21., 2 Kaposvár, Hódos-tó: 2018.06.26., 1.

Anax imperator (Leach, 1815): Balatonmáriafürdö, Nyugati-övcsatorna: 2015.05.17., 10; 2016.06.12., 2 - Barcs, 9. tó: 2014.05.10., 3; 2014.05.19., 1; 2014.05.24., 43; 2014.06.03., 12; 2014.07.01., 4; 2018.05.15., 1 - Barcs, Kisbók: 2019.05.10., 1 - Barcs, Ó-Dráva: 2018.05.17., 36; 2020.05.09., 1 - Barcs, Rinya, BSC: 2018.06.20., 1 - Barcs, Rinya, vasútállomás: 2015.06.16., 2 - Barcs, Vöröspart: 2015.06.13., 1 - Darány, Kaburgya: 2015.05.06., 1 - Darány, Nagyberek: 2014.05.21., 1 - Marcali, Gyótapusztai halastó: 2014.06.09., 1 - Somogytarnóca, horgásztó: 2018.05.12., 1.

Anax parthenope (Selys, 1839): Kaposvár, Töröcskei-tó: 2018.06.26., 1*.

Brachytron pratense (Müller, 1764): Barcs, Ó-Dráva: 2018.05.17., 1; 2020.04.19., 1 Barcs, Rinya, BSC: 2011.04.29., 2; 2014.04.09., 1; 2014.04.22., 1; 2019.04.22., 1; 2019.04.25., 1 - Barcs, Vöröspart: 2015.05.09., 1; 2016.05.25., 6; 2016.06.08., 2; 2018.05.16., 1; 2018.05.21., 1; 2018.06.07., 1; 2019.05.08., 1; 2020.04.22., 1. 


\section{Gomphidae Rambur, 1842}

Gomphus flavipes (Charpentier, 1825): Barcs, Dráva, kikötő: 2011.06.27., 3; 2014.06.19., 8; 2014.06.28., 4; 2014.07.21., 2; 2015.06.14., 1; 2015.06.18., 2; 2015.06.30., 6; 2015.07.06., 1; 2015.07.10., 2; 2015.07.19., 1; 2016.07.02., 1; 2017.06.16., 1; 2019.06.19., 4 - Barcs, Dráva, strand: 2011.07.01., 1 - Barcs, Drávapart: 2011.07.02., 4.

Gomphus vulgatissimus (Linnaeus, 1758): Barcs, Dráva, kikötő: 2011.05.15., 4; 2012.05.02., 2; 2012.05.10., 2; 2012.05.19., 1; 2012.06.27., 1; 2013.05.10., 2; 2013.05.13., 13; 2014.04.27., 45; 2014.05.01., 13; 2014.05.02., 29; 2014.05.07., 32; 2014.05.09., 36; 2014.05.11., 15; 2014.05.12., 10; 2014.05.14., 2; 2014.05.18., 1; 2014.05.20., 1; 2014.05.25., 1; 2015.05.04., 86; 2015.05.06., 42; 2015.05.10., 35; 2015.05.13., 17; 2015.05.18., 6; 2015.06.14., 1; 2016.04.20., 34; 2016.04.21., 18; 2016.04.22., 23; 2016.04.24., 26; 2016.04.26., 5; 2016.04.29., 13; 2016.05.05., 3; 2016.05.17., 2; 2016.05.20., 2; 2016.05.23., 1; 2018.04.29., 1; 2018.05.07., 5; 2019.05.07., 20; 2019.05.18., 18; 2019.05.23., 5; 2020.04.30., 1; 2020.05.02., 1; 2020.05.07., 2; 2020.06.04., 1 - Barcs, Dráva, Ringló: 2020.05.09., 1 - Barcs, Dráva, strand: 2015.05.04., 5 - Barcs, Dráva-part: 2011.05.18., 3.

Onychogomphus forcipatus (Linnaeus, 1758): Barcs, Dráva, kikötő: 2011.05.23., 1; 2014.06.19., 2; 2015.06.03., 1; 2015.06.18., 1; 2015.06.25., 1.

Ophiogomphus cecilia (Geoffroy in Fourcroy, 1785): Barcs, Dráva, kikötő: 2011.05.23., 21; 2011.05.27., 6; 2011.06.04., 4; 2011.06.27., 1; 2011.07.05., 1; 2012.06.27., 5; 2014.06.02., 3; 2014.06.05., 1; 2014.06.12., 3; 2014.06.19., 40; 2014.06.28., 12; 2014.07.21., 6; 2015.06.03., 12; 2015.06.09., 1; 2015.06.14., 9; 2015.06.18., 5; 2015.06.25., 5; 2015.06.30., 7; 2015.07.06., 1; 2015.07.10., 5; 2015.07.19., 3; 2016.06.09., 1; 2016.07.02., 3; 2017.06.16., 2; 2019.06.10., 1; 2019.06.19., 1 - Barcs, Dráva, strand: 2011.05.26., 14; 2011.06.14., 2; 2011.07.01., 1; 2012.06.03., 2; - Barcs, Dráva-part: 2011.05.18., 1; 2018.05.28., 1.

\section{Cordulegastridae Calvert, 1893}

Cordulegaster heros (Theischinger, 1979): Kaposvár, Hódos-tó-ér: 2018.07.04., 5 Szenna, Mátyás-kút: 2018.06.26., 3.

\section{Corduliidae Selys, 1850}

Cordulida aenea (Linnaeus, 1758): Barcs, Kisbók: 2018.05.29., 3; 2019.05.10., 5 Barcs, Ó-Dráva: 2014.04.28., 2; 2018.05.17., 4; 2020.04.19., 4 - Barcs, Vöröspart: 2015.05.09., 12; 2015.05.11., 4; 2015.06.13., 1; 2016.05.09., 4; 2016.05.21., 2; 2017.05.21., 1; 2017.05.30., 6; 2018.05.08., 9; 2018.05.18., 1; 2018.05.21., 3; 2018.06.07., 11; 2019.04.28., 46; 2019.05.08., 13; 2020.04.22., 18; 2020.05.03., 23*; 2020.05.04., 7*; 2020.05.10., 16*; 2020.05.14., 8; 2020.06.03., 7; 2020.06.06., 2 Bélavár, bányatavak: 2020.05.09., 7 - Marcali, Gyótapusztai halastó: 2014.04.21., 1.

Epitheca bimaculata (Charpentier, 1825): Marcali, Gyótapusztai halastó: 2014.04.21., 3.

Somatochlora flavomaculata (Vander Linden, 1825): Barcs, Vöröspart: 2018.05.21., 1; 2020.06.03., 1 . 


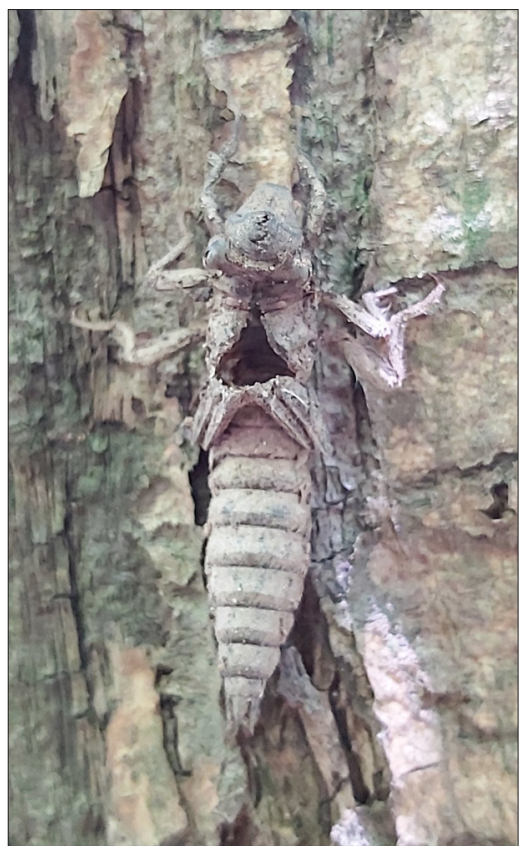

2. ábra: A Balkáni hegyiszitakötő

(Cordulegaster heros) lárvabőre

Libellulidae Rambur, 1842

Crocothemis erythraea (Brullé, 1832): Marcali, Gyótapusztai halastó: 2014.06.09., 2 Vörs, Zala-torkolat: 2015.06.21., 7.

Libellula depressa (Linnaeus, 1758): Barcs, Zimona: 2018.05.28., 1.

Libellula fulva (Müller, 1764): Barcs, Kisbók: 2019.05.10., 5 - Barcs, Rinya, BSC: 2011.04.29., 1;2011.05.20., 8;2016.05.06., 2;2016.05.07., 1;2016.05.20., 5; 2016.06.07., 1; 2017.05.21., 6; 2018.05.07., 5; 2019.05.02., 13; 2019.05.08., 16; 2019.06.17., 15; 2019.06.18., 1; 2019.06.19., 5; 2020.05.02., 1; 2020.05.07., 4; 2020.05.16., 2; 2020.06.04., 7 - Barcs, Vöröspart: 2014.06.05., 1; 2015.05.06., 214; 2015.05.09., 3; 2015.05.11., 2; 2016.05.09., 3;2016.05.21., 2;2016.05.25., 1;2016.06.08., 2; 2016.06.14., 3; 2017.05.21., 1; 2017.05.30., 3; 2018.05.08., 7; 2018.05.16., 5; 2018.05.21., 2; 2018.06.07., 1; 2019.04.28., 1; 2019.05.08., 6; 2020.05.03., 2; 2020.05.04., 7; 2020.05.10., $1+14 * ; 2020.05 .14 ., 3 ; 2020.06 .02 ., 2$; 2020.06.03., 5; 2020.06.06., 2; Marcali, Gyótapusztai halastó: 2018.05.20., 2.

Libellula quadrimaculata (Linnaeus, 1758): Bélavár, bányatavak: 2020.05.09., 2; Darány, Nagyberek: 2016.05.21., 1.

Orthetrum albistylum (Selys, 1848): Barcs, 9. tó: 2014.05.10., 3; 2014.05.19., 4; 2014.05.24., 10; 2014.06.03., 3; 2014.07.01., 8; 2015.06.11., 1; 2018.05.15., 1 - Barcs, Kisbók: 2018.05.29., 1 - Kaposvár, Deseda-víztározó: 2018.05.25., 1 - Kaposvár, Töröcskei-tó: 2018.06.26., 1; 2020.05.13., 1 - Marcali, Gyótapusztai halastó: 2018.05.20., 1 - Somogytarnóca, horgásztó: 2018.05.12., 1.

Orthetrum cancellatum (Linnaeus, 1758): Balatonmáriafürdő, Nyugati-övcsatorna: 2014.06.22., 2; 2018.07.02., 2 - Barcs, 9. tó: 2014.05.10., 1 - Barcs, Kisbók: 2018.05.29., 
1 - Barcs, Vöröspart: 2014.06.05., 1; 2015.06.23., 2; 2016.06.08., 1; 2016.06.14., 1; 2018.05.08., 1; 2018.05.16., 2; 2018.05.21., 1;2018.06.07., 1; 2020.05.10., 1; 2020.06.03., 3; 2020.06.06., 1 - Kaposvár, Töröcskei-tó: 2018.06.26., 1; 2020.05.13., 15 - Marcali, Gyótapusztai halastó: 2014.06.09., 1; 2018.05.20., 2.

Orthetrum coerulescens (Fabricius, 1798): Barcs, Rinya, BSC: 2019.06.17., 4; 2019.06.18., 1; 2019.06.19., 3 - Barcs, Rinya, vasútállomás: 2015.06.16., 2 - Barcs, Zimona: 2011.07.03., 2.

Sympetrum meridionale (Selys, 1841): Darány, Kaburgya: 2014.07.02., 22 - Darány, Kerek-tó: 2014.07.02., 14.

Sympetrum sanguineum (Müller, 1764): Balatonfenyves, Tenkes utca: 2014.06.21., 2 - Barcs, 9. tó: 2013.06.19., 3; 2014.07.01., 4; 2015.06.11., 1; 2016.06.14., 1 - Darány, Nyírkút: 2018.06.19., 10 - Barcs, Rinya, BSC: 2019.06.19., 2; 2020.07.11., 4 - Barcs, Vöröspart: 2014.06.05., 2; 2015.06.13., 7; 2015.06.23., 2; 2015.06.25., 1; 2015.07.01., 1; 2016.06.14., 1; 2018.06.07., 3; 2020.06.25., 1 - Darány, Kaburgya: 2014.07.02., 9 Darány, Kerek-tó: 2014.07.02., 14 - Kaposvár, Deseda-víztározó: 2018.05.25., 1 Marcali, Boronka-patak: 2014.06.21., 2 - Marcali, Gyótapusztai halastó: 2018.05.20., 4. Sympetrum striolatum (Charpentier, 1840): Barcs, 9. tó: 2013.06.19., 4.

Sympetrum vulgatum (Linnaeus, 1758): Balatonfenyves, Tenkes utca: 2013.06.24., 1 Barcs, 9. tó: 2013.06.19., 1 - Darány, Nyírkút: 2018.06.19., 1.

\section{Megvitatás}

A gyüjtések során előkerült 2168 exuvium 31 fajba sorolható, ez a Somogy-megyéből eddig ismert 55 szitakötő faj 56 \%-a. Közül a jelenleg hatályban lévő 66/2015. (X. 26.) FM rendelet alapján 8 védett (Aeshna isoceles, Gomphus flavipes, Gomphus vulgatissimus, Onychogomphus forcipatus, Ophiogomphus cecilia, Epitheca bimaculata, Somatochlora flavomaculata, Libellula fulva) és 1 fokozottan védett (Cordulegaster heros). A Magyar Vörös Listán (2017) 4 faj szerepel, veszélyeztetett (EN): Epitheca bimaculata, sérülékeny (VU): Ophiogomphus cecilia, Cordulegaster heros, Somatochlora flavomaculata. A Cordulegaster heros az Európai Vörös Lista (2010) fenyegetett (NT) besorolású faja (2. ábra).

A fellelt exuviumok alapján fajokban leggazdagabb élőhelynek a 9. tó (Barcs), a Vöröspart (Barcs) (1. ábra) és a Gyótapusztai halastó (Marcali) bizonyultak (2. táblázat). Kiemelendő, hogy Barcsnál a Drávából mind a négy folyami szitakötő exuviuma előkerült, ami azt igazolja, hogy a Dráva folyónak ez a szakasza is ökológiailag értékes, változatos élőhely. 


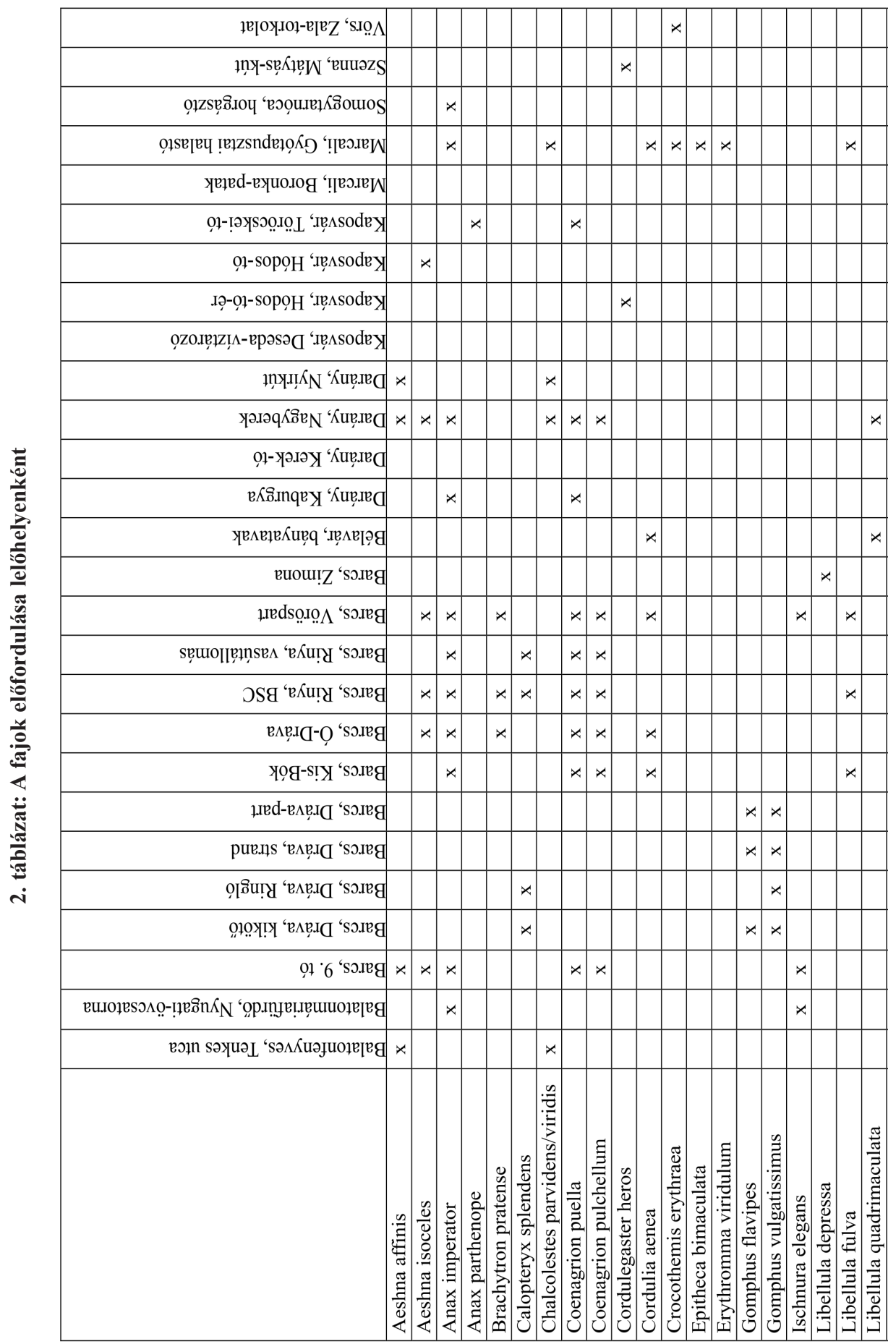




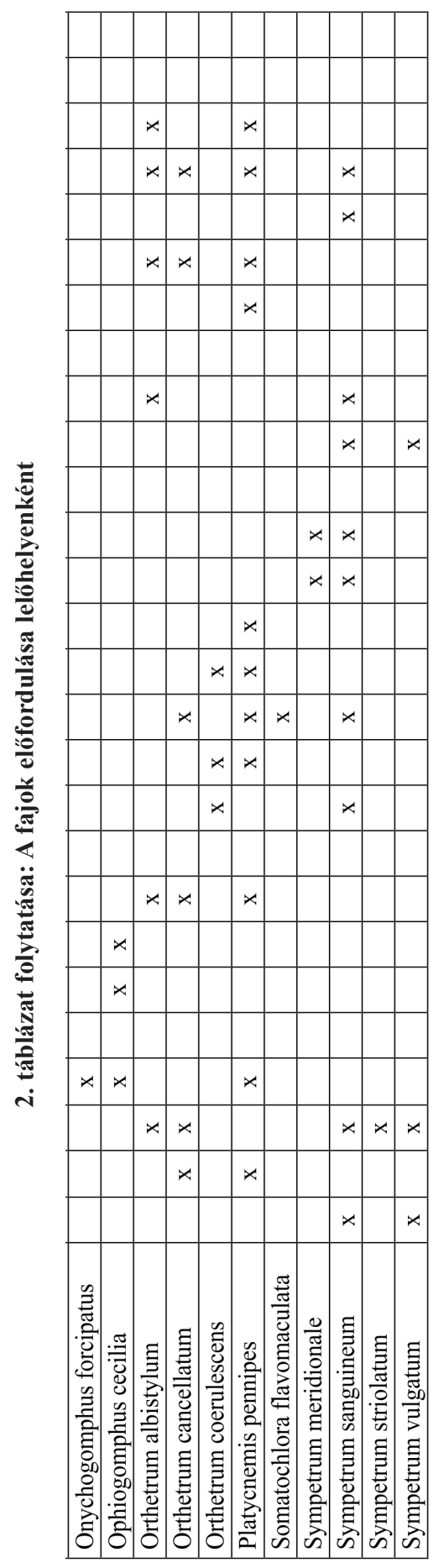




\section{Irodalom}

ANONIm 2015: 66/2015. (X. 26.) FM rendelet „Az elkobzott védett természeti értékekkel kapcsolatos intézkedésekröl szóló 19/1997. (VII. 4.) KTM rendelet, valamint a védett és a fokozottan védett növényés állatfajokról, a fokozottan védett barlangok köréröl, valamint az Európai Közösségben természetvédelmi szempontból jelentős növény- és állatfajok közzétételéről szóló 13/2001. (V. 9.) KöM rendelet módosításáról”. - Magyar Közlöny 158: 20844-20949.

DÉVAI Gy. 1981: Újabb adatok a Barcsi Borókás szitakötő (Odonata) faunájához. - Dunántúli dolgozatok, Természettudományi sorozat 2: 53-58.

DÉvai Gy., Kurucz M. 1978: A Barcsi Ősborókás szitakötő (Odonata) faunája. - Dunántúli dolgozatok, Természettudományi sorozat 1: 61-78.

DÉvai Gy., Miskolczi M. 1993: A Barcsi Borókás Tájvédelmi Körzetben 1981-1985 között végzett szitakötőgyüjtések (Odonata) faunisztikai eredményei. - Studia odonatologica hungarica 1: 21-32.

DÉVAI GY., Miskolczi M. 2010a: A Barcsi Borókás Tájvédelmi Körzetben 1987-ben végzett szitakötőgyűjtések (Odonata) eredményei. - Studia odonatologica hungarica 11: 53-59.

DÉvAi Gy., Miskolczi M. 2010b: Adatok a Drávamelléki-síkság szitakötő-faunájához (Odonata). - Studia odonatologica hungarica 11: 61-68.

DÉvai Gy., Miskolczi M. 2010c: Adatok a Zselic szitakötő-faunájához (Odonata). - Studia odonatologica hungarica 11: 69-76.

FARKAS S. 2020: Magyarországi nagyszitakötők (Anisoptera) lárvabőreinek képes határozókulcsa. - https:// legivadasz.hu/wp-content/uploads/Exuvium_hatarozokulcs_Anisoptera_20.pdf

FARKAS S. 2021: Magyarországi kisszitakötők (Z̄ygoptera) lárvabőreinek képes határozókulcsa. - https://legivadasz.hu/wp-content/uploads/Exuvium_hatarozokulcs_Zygoptera_1_0.pdf

Koнаuт R. 1896: A magyarországi szitakötő-félék természetrajza. - Királyi Magyar Természettudományi Társulat, Budapest $78 \mathrm{pp}$.

Kovács T., Ambrus A., Juhász P., Bánkuti K. 2004: Lárva és exuvium adatok Magyarország Odonata faunájához. - Folia historico-naturalia Musei Matraensis 28: 97-110.

Kovács T., Ambrus A., DanyiK T., Olajos P. 2017: Magyarország szitakötőinek Vörös Listája és faunisztikai bibliográfiája (Odonata). - Folia historico-naturalia Musei Matraensis 41: 25-58.

Kovács T., Ambrus A., Danyik T., Olajos P. 2018: Magyarország szitakötőinek kézikönyve. - Magyar Természettudományi Múzeum, Herman Otto Intézet Nonprofit Kft., Budapest 2018. pp. 1-290.

Móra A. 2019: A Barcsi Ó-Dráva holtág szitakötő faunája (Odonata). - In: Purger D., Purger J. J. szerk.: A Barcsi Ó-Dráva holtág élőhelyei és élővilága. BioRes. 2019. pp. 107-121. Pécs.

Tóтн S. 1995: A Dráva mente szitakötő (Odonata) faunájának előzetes vizsgálata. - Dunántúli dolgozatok, Természettudományi sorozat 8: 41-52.

Tóтн S. 1998: A Duna-Dráva Nemzeti Park Dráva menti területének szitakötő (Odonata) faunája. - Dunántúli dolgozatok, Természettudományi sorozat 9: 135-150.

Tо́тн S. 2001: Somogy megye szitakötőinek katalógusa (Insecta: Odonata). - Natura Somogyiensis 1: 93-99.

Tóтн S. 2003: A Látrányi Puszta Természetvédelmi Terület szitakötő (Odonata) faunája. - Natura Somogyiensis 5: 85-97.

Tо́тн, S. 2005: Monitoring dragonflies on the section of the Dráva between Örtilos and Vízvár (Insecta: Odonata). - Natura Somogyiensis 7: 35-48.

То́тн S. 2006: A ritka hegyiszitakötő (Cordulegaster heros Theischinger, 1979) előfordulása a Zselicben. Natura Somogyiensis 9: 141-144.

Tóтн S. 2010: A Dunántúli-dombság és környéke szitakötő faunája. - Natura Somogyiensis 16: 1-188. 